\title{
LITHUANIAN SLANG ADVERBS OF SLAVIC ORIGIN
}

\author{
Robertas KUDIRKA \\ Vilnius University
}

\section{Introduction}

A social dialect is always related to a certain region, predominant in a certain territory with the status of language and the ethnic composition of the population, i.e., with territorial dialects (Chambers, Trudgill 2004: 45-46). A number of Slavisms (Belarusianisms, Polonisms, Russianisms) have appeared in Lithuanian due to constant and close contact between Lithuanian and Slavic languages. Because of the commonality of Slavic languages, it is not always possible to determine from which language the word came; therefore, it is simply considered to be a Slavism. Only a minor part of Slavisms were accepted and became the norm of the standard language, and Russianisms are mostly used in nonstandard everyday language, vernacular, slang. Also, a large part of the nonstandard Slavic lexicon appeared due to the forced bilingualism and Russification carried out in Soviet-occupied Lithuania (1944-1990). ${ }^{1}$

Borrowing is a constant process in a language and is particularly pronounced in slang, since borrowing allows for a constant updating of the vocabulary, replacing words with more expressive ones for stylistic reasons, etc. A foreign language unit that arises in the context of another language undergoes assimilation - it is transformed in one way or another by adapting it to the linguistic system. The level of adaptation is directly related to the relationship between the two language (or several, if there are language intermediaries) systems. The adaptation of a foreign word, borrowed into the grammar of the language (orthography, phonology, morphology) can be of several stages and types - these features are especially noticeable in nonstandard language. The phenomenon of borrowing adaptation can be described in three stages: zero, partial, and complete (cf. Filipović 1980: 2-5). According to the degree of adaptation, borrowings can be divided

1 In order to Russianize the institutions of Lithuanian administration, the leadership of the Communist Party (Bolsheviks) accelerated the migration of Russians to Lithuania, many of whom were employed in administrative institutions. The Russian language prevailed in institutions, and Soviet destructive ideology was concealed by the so-called proletarian internationalism (Anušauskas 1996; Tininis 2008). 
into: a) completely unadapted ${ }^{2}$, b) adapted only orthographically and phonetically, phonologically, c) adapted orthographically, phonetically and morphologically. Such a full adaptation of and integration of borrowed vocabulary (semantic and syntax aspects should be added) is universal in many languages (Treffers-Daller 1994: 243-244; Irwin 2011: 44-53; Sharp 2001: 30; Sunde 2018: 85-88; Durkin 2014). Morphological adaptation is already a sign of a borrowing integration into the system and has several subtypes: (1) obtaining incectional endings, (2) adding a derivational suffix, (3) changing a derivational suffix (the derivational suffix of a donor language is replaced by the suffix of a recipient language) (cf. Pakerys 2016: 264; Wohlgemuth 2009: 56; Valeckiene 1967: 128). The derivation of the derivative with its own suffix from the borrowing as well as adaptation with affixes (derivation according to semantically close derivatives with affixes) are a confirmation that integration that has already taken place (Urbutis 2009: 137-138; LKE 1999: 15).

The above-mentioned degrees of adaptation can be illustrated by several examples of slang. The borrowed infinitive achujiete', achujęt' (Russ. vulg. oxyémb $)^{3}$ is adapted in several ways phonetically and orthographically with the meaning 'to go crazy' (va cia tai axujiet galima, nuotaika ishvis sugadino) ${ }^{4}$. This infinitive is adapted in hybrid fashion morphologically with the suffix -inti: achujielinti, achujelinti 'to become surprised; to go nuts (cf. past tense forms, sg. 1, 2, 3 pers.: охуе́л, pl. 1, 2, 3 pers.: охуе́ли) - the verb can be conjugated. The adjective of the same root with the suffix -nas (Russ. -нbiŭ) is adapted phonetically, orthographically and with the ending -as morphologically: achujienas, achujennas, - $a$ (Russ. vulg. охуе́нньий) with the meaning 'great' (Ale gi achujienas kürinys!); 'big' (Beto gi nelabai senas lupenas varo i lietuva muitai achujieni.). The addition of an inflectional ending (-as) indicates the integration of the borrowing into the system. Further, a hybrid adverb is consistently derived from the adjective - the derivational suffix -ai establishes an orthographic and phonetic integration: achujuenai, achujenai 'great, well' (Taip atrodo achujenai, bet ir kainuoja neblogai.); 'a lot' (isvada -

2 Zero adaptation is theoretical - more commonly used borrowing is naturally phonetically adapted according to the principle of substitution of foreign phonemes as close as possible to its own.

3 All the Russian words, except for monosyllabic, are stressed with a single stress (') used in the Russian language (only the grapheme $-\ddot{e}$ - is left without a stress as it is always stressed). For Lithuanian slang words the base of the stressed syllable (vowel, diphthong) is underlined. An apostrophe after the consonant (e.g., tol' $k a$ ) indicates the softness of the consonant.

4 Illustrative examples have not been edited: examples of slang of written language from the internet are without diacritics, writing without diacritics is the norm in internet slang. 
reik turet achujenai daug babkiu.). Such a derivative can be also formed by affix adaptation - simply from the Russian adverb - by changing the derivative suffix of the donor language to the suffix of the recipient language: the adverb achüienai is formed by simply adapting the Russian adverb охуе́нно (replacing the Russ. adverbial suffix -o), rather than from the adjective achujienas.

In standard Lithuanian, only a minor part of borrowings are uninflected; research has shown the tendency to morphologically adapt almost all borrowings (Rimkutè 2010; Jakaitienè 2009: 236). Also, in Lithuanian slang, the majority of slang words integrate into the derivational and inflectional paradigms of Lithuanian and only a small part remain morphologically unadapted. This typical and systematic pattern for slang can be illustrated by the root words of

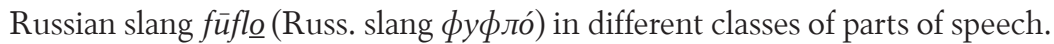
Sometimes the lexeme can be only adapted orthographically and phonetically: füflo is used as an adjective meaning 'great, original; strange, crazy', and as an adverb 'greatly, originally; strangely, crazily'. However, in usage, the morphologically unadapted form füflo (cf. Russ. фуфло́) remains more remote; the productive grammatical categories of the noun (gender, number, case) are realized in a standard way during adaptation. Morphologically unformed forms of borrowings that are entrenched in usage have a tendency to become inflected in the long run - the addition of an inflectional ending indicates the integration of the borrowing into the system, e.g.: füflas 'falsification; nonsense'. The addition of a derivational adjective ending -iškas only establishes orthographic and phonetic integration: füfliškas, $-a$ 'forged; poor'. In the slang form, it is noticeable that by copying the derivative model of the standard language from the adjective füfliškas, $-a$ the adverb is formed with the suffix -ai: füfliškai 'forged; poorly'. It is natural that the system also has some rare suffixes, e.g., -avas: adjective füflavas, $-a$.

A derivative can also be formed by changing the derivational suffix (the derivational suffix of the donor language is replaced by the suffix of the recipient language): the adverb füflovai is made simply by transposing from the Russian adverb фуфло́во (the suffix of the Russian adverb -о is replaced with Lithuanian adverb -ai), and not from the Lithuanian slang adjective füflovas, $-a$. However, such a formation of adverbs from Russian is rare and atypical.

Slavic slang is characterized by several typical features of phonetic adaptation. In unstressed syllables of Russian words a reduced /a/ is pronounced instead /o/ (RG 1980: 25-27; Avanesov 1984: 51-60; Gorbačevič 1989: 35-42). The pronunciation of the vowels /a/ and /o/ at the beginning of a borrowed slang word may vary, but such pronunciation is rarer, cf.: 
achujiennas, ochujiennas, - - (Russ. vulg. охуе́нныій); biestalkovas, biestolkovas (Russ. бестолко́вый). This feature is taken over by the adverbs derived from

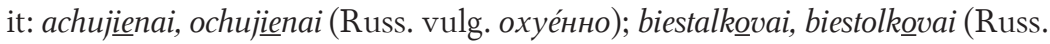
бестолко́во). This feature is rather consistently applied when borrowing Russian words as well. The sound /o/ in such cases is probably used by more literate informants (in the written form: Russ. adv. vulg. охуе́нно, офиге́нно), but it is rare.

The present slang words of Slavic origin are also characterized by a systematic variation of the root vowel /e/, / ie/ with diphthongized or otherwise varied vowels. Slang adverbs accept this feature from the base words adjectives: vięčnas, vẹčnas (Pl. wieczny, Russ. ве́чнытй); abaldienas, abaldenas (Russ. slang обалде́ннылй); cherovas, chierovas, $-a$ (Russ. vulg. херо́вы й) etc. ${ }^{5}$ Adaptation to such variation may also be influenced by normative words of co-origin, e.g.: šviežias (cf. Russ. све́жиŭ, Pl. świeży) or /e/-/ie/ diphthongization areas of territorial dialects found throughout the Lithuanian language area (Urbanavičienė 2018: 59; Kardelis 2009: 100-139). Old Slavisms presented in the normative publications of the standard language (see KPP 1985) also have a variable root vowel /ie/, /e/: peškom, pieškom (Pl.pieszo, Russ. пешко́м); čierka, čerka (Pl. czarka, Belarus. чápка); siemkos, semečkès (Russ. vern. се́мки, Russ. се́мечки) еtc. Old Slavisms can also have a nonvarying diphtong /ie/: padielka (Russ. подделка), padjiezdas (Russ. подъезд), pieška (Russ. vern. пешка), svietas (Pl. świat, Belarus. свет, Russ. свет), biesinti (Russ. бecúmb, cf. Pl. bies 'evil') etc. (KP 2005).

The aim of this article is to morphologically examine different types of slang adverbs: hybrid derivatives of the suffix -ai from suffixal Slavic adjectives, hybrid derivatives of the suffix - ai from Slavic adjectives without suffixes, slang adverbs of Slavic origin without formants, adverbialized word combinations of Slavic origin.

For selected adverbs, the origin of the slang word was first determined and then the word was analyzed morphologically. Derivationally segmentable adverbs are classified according to the suffixes of the derivative base, and a systematic analysis is performed in order to refine the prevailing derivative models, to discuss the relations of those models. Derivationally nonsegmentable forms (adverbs without formants and adverbialized word combinations) are described in terms of phonetic adaptation. The analysis aims to identify

5 Also, the old Slavisms have both a variable root vowel (peškom, pieškom (Pl. pieszo, Russ. пешко́м)), and a nonvariable (рadielka (Russ. подделка), biesinti (Russ. бесúmb, cf. Pl. bies 'evil')), etc. (for more, see KP 2005; KPP 1985). 
systematic morphological features and general structural patterns. The material was collected from Dictionary of Lithuanian Slang and Nonnormative Lexicon (Kudirka 2012) and the supplementary electronic database of this dictionary, which has been updated in 2020 (the dictionary consists of more than 9360 headwords.). The collection of the material started in 1998. The material in this dictionary was collected from two sources: (a) spoken language and (b) online forums and interactive online chats via text messages (mIRC, Skype, etc.). Material for the vocabulary has not been collected from printed (,paper“) sources, fiction, etc. texts that could have been edited. Certain social areas - prison, criminal, drug addicts, soldiers and so on. - slang was collected solely from spoken language, recording with a dictaphone during personal conversations - in this way almost all words of these areas were collected (for more details, see Kudirka 2012: 3-5). The base words of hybrid derivatives are provided from explanatory dictionaries (Czeszewski 2006; Vaitkevičiūtė 2003; Kveselevič 2005; Mokienko, Nikitina 2000).

Usually, the research of borrowings focuses on nouns, adjectives, and verbs (Pakerys 2014; Pakerys 2016; Girčienè 2005; Vaicekauskienė 2007). There is no separate, systematic, and detailed lexical research of Lithuanian slang.

\section{Morphological features of an adverb}

An adverb is the most dynamic part of speech and is particularly diverse. The first feature of the adverb is its non-inflectionality (only part of adverbs are graded), the adverb ends with: (1) a derivational formant, (2) the suffix of the derivational base, (3) simply the stem, the ending of the derivational base which does not serve as an ending (LKG II 1971: 425; Paulauskiene 1994: 378). Adverbs also differ from other parts of speech in that they can be formed from various inflectional parts of speech or word combinations, but usually, adverbs are made from adjectives with the suffix -ai (LKG II 1971: 426; BSŽ 2004). It is important to understand that relations among standard, standardized and nonstandard language are not spontaneous, since most of these phenomena are like a junction of such systems (standard language and nonstandard language) with their own patterns.

\subsection{Hybrid derivatives with Lithuanian slang suffix -ai from suffixal adjectives of Slavic origin}

Lithuanian slang is especially rich in suffixal derivatives (70) formed from adjectives of Slavic origin with the suffixes -nas and -ovas. Other 
suffixes are less common: -(i)avas (12), -skas (7), -telnas (5), -nutas (5), -ovatas (-avotas) (3), -yvas (2).

\subsubsection{Derivatives with suffix -ai from adjectives with the suffix -nas}

The majority (37) of adverbs are derived from base adjectives of Russian origin with the affix -nas (adapted from Russ. -Hbiŭ) (RG 1980: 269-270); most of these adjectives in Russian are slang or colloquial. A small part of the base slang adverbs can be also related to the Polish adverbial suffix -ny (cf.: blatnas: Russ. блатно́й, Pl. blatny) (GWJP 1999: 494-496).

In Lithuanian slang, hybrid adverbs with suffix -ai (e.g., abaldienai, prav$\underline{\text { alnai) }}$ are formed from Lithuanian slang adjectives that are usually borrowings from Russian (abaldiennai: abaldiennas (Russ. slang adj. обалде́нный), pravalnai: pravalnas (Russ. adj. прова́льньй) but not from Russian adverbs: adv. slang обалде́нно, adv. прова́льно. However, in the list, the base word is followed by the Russian adverb too (if it exists) with the abbreviation (cf.), because in some cases such derivation is also possible: abaldienai, abaldenai 'greatly' (: abaldienas, abaldenas, - $a$; cf. Russ. adv. slang обалде́нно), abydnai 'disap-

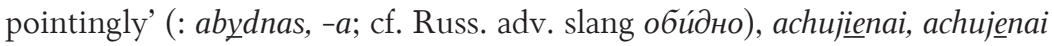
'greatly' (: achujiennas, achujennas, -a; cf. Russ. adv. vulg. охуе́нно), afigienai,

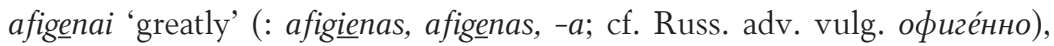
baldiozznai 'impressively' (: baldiozžnas, - $a$; cf. Russ. adv. slang балдёжно), bardačnai 'messily (: bardačnas, - $a$; cf. Russ. adv. vern. барда́чно), bespredielnai, bespredelnai 'overstepping the bounds' (: bespredielnas, $-a$; cf. Russ. adv. coll. беспреде́льно), bezabydnai 'not offensively, peacefully' (: bezabydnas, - $a$; cf. Russ. adv. безоби́dно), blatnai 'uniquely' (: blatnas, -a), chaliavnai 'freely' (: chaliavvnas, $-a$; cf. Russ. adv. vern. халя́вно), chaltūrnai 'nonqualitatively (: chaltūrnas, $-a$; cf. Russ. adv. coll. халти́рно)...6

\subsubsection{Derivatives of the suffix -ai from adjectives with the suffix -ovas}

A major (33) group of adverbs originate from base slang adjectives of Russian origin with the suffix -ovas (Russ. -овый (orthographically also -евыли) (RG 1980: 276). The semantics of this suffix is very broad and usually 'indicates the relationship with the subject matter expressed by the base word' (e.g.: столо́выцй 'table, of a table'). A part of the slang adjectives

6 If there are more than ten examples, they are presented in the appendix below. The words quoted in the article are not repeated in the appendix. 
may be related in origin to the Polish adverbial suffix -owy (cf. chujovas, -a: Pl. adj. vulg. chujowy) (GWJP 1999: 493). In this subsection, as well as in other cases, in Lithuanian slang hybrid adverbs with the suffix -ai (e.g., biestalkovai, chrienovai) are formed from Lithuanian slang adjectives that are borrowings from Russian (biestalkovai: biestalkovas, - a (Russ. adj. бестолко́выıй), chrienovai: chrienovas, - (Russ. adj. vulg. хрено́выıй) and not simply from Russian adverbs - adv. slang бестолко́во, adv. vulg. хрено́во (derivation directly from Russian adverbs is characterized as rare, atypical). Hybrid adverbs from root slang adjectives of Russian origin with the suffix -ovas: bespantovai 'unintentionally' (: bespantovas, - $a$, cf. Russ. adv. slang беспонто́во), biestalkovai, bestalkovai 'pointlessly' (: biestalkovas, bestalkovvas, - $a$; cf. Russ. adv. бестолко́во), chierovai, cherovai 'badly' (: chierovas, cherovas, -a; cf. Russ. adv. vulg. херо́вo), chrienovai, chrenovai 'badly' (: chrienovas, -a; cf. Russ. adv. vulg. хрено́во), chrinovai 'badly' (: chrinovas, -a), chujovai 'badly' (: chujovas, - ; cf. Russ. adv. vulg. хуёво, Pl. adv. vulg. chujowo), depresovai 'depressively' (: depresovas, -a; cf. Russ. adv. slang депресо́во), dermovai 'awfully' (: dermovvas, - $a$; cf. Russ. adv. vern. дерьмо́во), dešovai 'cheaply' (: dešovas, - $a$; cf. Russ. adv. дешёвo), figovai 'poorly' (: figovas, $-a$; cf. Russ. adv. vern. фиго́во).

There are borrowings from the field of music from English into Russian itself, hybridly adapting the suffix -овый: pankovai 'pank' (: pankas; cf. Russ. adv. па́нково, Eng. punk), рорsovai 'in a pop way' (: popsovas, -a; cf. Russ. adv. slang nопсо́во), repovai 'characteristic of rap' (: repovas, - $a$; cf. Russ. adv. pэ́nово), rokovvai (: rokovas, -a; cf. Russ. adv. ро́ково), hipovai 'in a hippy manner' (: hipovas, - $a$; cf. Russ. adv. vern. хипnóвo). Among recent borrowings in Russian: bugovai 'with errors' (: bugovas, -a; cf. Eng. bug 'software error'), draivovai 'impressively' (: draivovas, - $a$; cf. Russ. adv. slang драйво́во; cf. Eng. drive 'impetus, inner impulse'), kreizovai 'crazily' (: kreizovas, -a; cf. Russ. adv. slang кре́ŭзово, Eng. crazy 'crazy'), seksovai, sexovai 'in a sexy manner' (: seksovas, sexovas, -a; cf. Russ. adv. slang сексо́во).

\subsubsection{Derivatives with suffix -ai from adjectives with suffix -(i)avas}

A minor part (12) of adverbs originates from base adjectives with the suffix -avas, -iavas (Russ. -авьий, -явьий: кровавьій, дьрявылй; cf. Pl.-ашу: ciekawy; cf. Ukr. ціка́вий, Belarus. ціка́вы) (RG 1980: 287; GWJP 1999: 489). There are very few adjectives with the suffix -avas in slang, since the semantics of this suffix are duplicated by derivatives with the suffix -ovas. There are cases where slang words of the same root have both suffixes; 
however, derivatives with suffix -ovas are used more often: seksovas and (rarely) seksavas, stiliovas and (rarely) stiliavas, (rarely) rokavas and rokovas. However, there are derivatives with the suffix -avas that are not used with -ovas: cekavai 'curiously' (: cekavas, -a), chaliavai 'for free' (: chaliavvas, -a), nachaliavai 'for free' (: nachaliavas, -a, cf. Russ. adv. vern. на халя́ву), nachaliavnai 'for free' (: nachaliavnas, -a, cf. Russ. adv. vern. нахаля́вно).

Some slang words are already formed in a hybrid manner in Lithuanian with the suffix -avas. Since in Russian slang there are no such words, they seem to be pseudo-borrowings (see the term Vaicekauskiene 2007: 19) or pseudoanalogical derivatives (Urbutis 2009: 328), i.e. formed on the pattern of foreign words: bachūravas, $-a$, chronciavas, $-a$, chroniavas, $-a$, forsavas, $-a$, šyzavas, $-a$, etc. In such cases, adjectives are already formed in Lithuanian slang according to derivational analogy, since there are no such adjectives in Russian. These adjectives are the derivational base for the following adverbs: chrienavai, chrenavai rar. 'poorly' (: chrienavas, chrenavas, $-a$ ), chroniavai 'as a chronic alcoholic' (: chroniavas, -a), monavai tech. 'mono-, with one loudspeaker' (: monavas, $-a$ ), popsavai 'in a pop way' (: popsavas, $-a$ ), rokavai 'characteristic of rock music' (: rokavas, -a), seksavai, sexavai rar. (: seksavas, $-a$ ), steria $\underline{a} a i$ 'stereophonically' (: steriavaas, -a), stiliávai 'stylishly' (: stilia $v a s,-a)$.

\subsubsection{Derivatives with suffix -ai from adjectives with suffix -skas}

In slang there are few (7) hybrid adverbs with adjectival affix -skas; derivatives with this suffix can be both from Russian (-скиŭ, longer variants: -енский, -еский, -овский), and from Polish: (-ski, longer variants: -ański, -cki, -eński, -iński, -owski) (RG 1980: 291; GWJP 1999: 494): amerikanskai 'in the American way' (: amerikanskas, -a; cf. Russ. adv. по-америка́нски), babskai 'womanishly' (: babskas, -a; cf. Russ. adv. coll. по-бáбскu), bandítskai 'in a ruffian manner' (: banditskas, -a; cf. Russ. adv. по-бандúmски), žydovskai 'in a Jewish way' (: žydovskas, - $a$; cf. Pl. adj. żydowski, Russ. adv. по-жидо́вски), zajebatelskai 'amazingly' (: zajebatelskas, -a), zajibatelskai 'amazingly' (: zajibatelskas, -a), kacapskai 'in a Russian way' (: kacapskas, - $a$, cf. Russ. adv. по-каца́пски).

\subsubsection{Derivatives with suffix -ai from adjectives with suffix -telnas}

There are few (5) derivatives with suffix -telnas (Russ. -тельньй) (RG 1980: 290): achujabytielnai, achujabịtelnai 'greatly' (: achujabytielnas, achujabitielnas, -a), achujiebytielnai, achujebitelnai 'in a very cool way' (: achujiebytielnas, achujebitelnai, - $a$; cf. Russ. adv. vulg. охуеби́тельно), асhијұtielnai, achujịtelnai 'in a very cool way' (: achujytielnas, achujịtelnas, $-a$; cf. Russ. adv. 
vulg. охуи́тельно), afigytielnai, afigitelnai 'very' (: afigytielnas, afigịtelnas, -a; cf. Russ. adv. vulg. офиги́тельно), pochujytielnai, pochujitelnai (: pochujytielnas, pochujïtelnas, $-a$, cf. Russ. adv. vulg. похуúmельно).

\subsubsection{Derivatives with suffix -ai from adjectival participles with suffix -nutas}

All the base words of the adverbs in this subsection are adjectival Russian passive participles with the suffix -тьıй, e.g.: чо́кнутьий, ебану́тьий. All the base words of these adverbs have the verbial suffix $-н y$-, thus, the entire ending of derivatives is -нymbıй (RG 1980: 668). In slang, there are only several (5) adverbs, the majority of which are rarely used, and their meaning is similar 'bad, not well': čionknutai (: čioknutas, -a), jebanutai (: jebanutas, -a), jobanutai (: jobanutas, $-a)$, jobnutai (: jobnutas, $-a)$, pyzdanutai, pizdanutai (: pyzdanutas, pizdanutas, $-a$ ).

\subsubsection{Derivatives with suffix -ai from adjectives suffixes -ovatas, -avotas}

Several hybrids (3) are related to the compound suffix of Russian adverbs -овато (orthographically also-евато). It is derived from adjectival suffix -оватылй, meaning part of a feature, a small degree of a feature (cf., красный > краснова́тьий 'reddish, slightly red') (RG 1980: 285). Also, the suffix of root adjectives can be derived from Polish: -owaty (GWJP 1999: 489). There are only two hybrids derived from base words with this suffix: pyzdavotai, pizdavotai 'poorly' (: pyzdavotas, -a; cf. Russ. adv. vulg. пиздовámo, Pl. adv. vulg. pizdowaty), debilavotai 'retardedly' (: debilavotas, - $a$; cf. Russ. adv. vern. дебилова́mо). With the suffix variant -еватьй there is only one hybrid adverb chujovatai 'badly' (: chujovatas, - $a$; cf. Russ. adv. vulg. хуевámo).

\subsubsection{Derivatives with suffix -ai from adjectives with suffix -yvas}

There are only two slang adverbs derived from base adjectives with the suffix -yvas (Russ. - ивbiǔ): falš̌vai 'falsely' (: falš̌zvas, - $a$; cf. Russ. adv. фальши́во), paršyvai 'poorly' (: paršyvas, - $a$; cf. Russ. adv. nаршúвo).

\section{Derivatives with suffix -ai from Slavic adjectives without suffixes}

There are a significant number of slang adverb derivatives from adjectives without suffixes (17). In slang, the base words of these derivatives with 
the suffix -ai from hybrid adverbs are usually primary two-syllable adjectives of Russian origin (e.g., čiótkai 'splendidly' : adj. čiótkas, $-a$ ). They could be made from adjectives as well as in certain cases from Russian adverbs, thus, where possible, adverbs are also given in brackets. In these cases, the formation of adverbs from adverbs is a specific phenomenon of morphological adaptation, since in the Russian language system $-o$ is a true adverbial suffix (e.g., кру́то, чётко), which can be simply rejected (cf. Valeckienė 1967: 128, Girčienè 2012: 33). Such a method of morphological adaptation when the derivational suffix of the donor language is replaced by the suffix of the recipient language is also described in the research of borrowed adjectives (Pakerys 2016: 247). There are similar cases in slang when in the same way morphological pseudo-borrowings, words formed on the basis of foreign word patterns, are made, e.g.: bachūravas, - $a$, forsavas, $-a$, etc. (Görlach 2002: 29-30; Fisher 2008: 7).

In this subsection there are 17 adverbs: chaliavai 'for free' (: chaliavas, $-a$ ), čiornai 'heavily; extremely intensively' (: čiornas, -a; cf. Russ. adv. чернó), čiotkai 'splendidly' (: čiotkas, - $a$; cf. Russ. adv. slang чётко), jasnai 'clearly' (: jasnas, - $a$; cf. Russ. adv. я́сно), kliovai 'greatly' (: kliovas, - $a$; cf. Russ. adv. slang клёво), krūtai 'in a very cool way' (: krūttas, - $a$; cf. Russ. adv. coll. крýmo), lievai 'badly' (: lievas, $-a$; cf. Russ. adv. slang лéвo), miortvai 'deadly' (: miortvas, - $a$; cf. Russ. adv. мёртво), nachaliavai 'for free' (: nachaliavas, $-a$, cf. Russ. adv. vern. на халя́ву), naglai 'rudely' (: naglas, - $a$; cf. Russ. adv. на́zло)...

\section{Slang adverbs of Slavic origin without formants}

In Lithuanian slang, morphologically unadapted borrowed forms are not commonly used, since they are not adapted to derivational and inflectional paradigms. However, there is a group (22) of morphologically unadapted Slavic borrowings without formants that are used in slang only as adverbs: dabro 'well; greatly' (Russ. coll. добрó), karočia, karoče (Russ. coll. коро́чe) 'in a word, in short', slabo 'too weak, unable'.

Some of the borrowed adverbs, when used, have phonetically altered and deformed variants: vabšs $\underline{e}$ vabšie ; vobšče, vobščie; vobšs $\underline{e}$, vobšie (Russ. воoбщé) 'overall, in general', von, vun, vūn (Russ. coll. вон) 'get out, go away'.

The slang words $\underline{a m} b a, \underline{a m b o}$ (Russ. vern. ám6a, Pl. coll. amba), kajuk (Russ. vern. каю́к), kirdych, kirdцk (Russ. vern. кирдь́к), chana (Russ. coll. хана́) meaning 'badly' can be used as predicative adverbs. Some borrowed adverbs are integrated into an inflectional or derivational system: they are alternatively used with an adapted suffix (kajukai) or ending (kirdykas). 
The vulgarism chui (Russ. vulg. xyŭ) meaning 'any, nothing' can be also used as an adverb: Chui tu ją atplèši! // Chui ten firma, šaraga kažkokia neaiški. Euphemisms chrien, chren (Russ. vulg. хрен), chier, cher (Russ. vulg. xep), fig (Russ. vern. фuz) are also predicatively used as an adverb with a meaning 'any, nothing'. Vulgarisms dermo (Russ. vern. vulg. дерьмó), gavno (Russ. vulg. говно́, Pl. vulg. gówno) also can be used predicatively as an adverb meaning 'badly; shit': zodziu gavno gavos su amerikanska plevele, su kiniska gal ir geriau butu buve.

\section{Adverbialized word-combinations of Slavic origin}

Adverbialized word combinations are rather common in slang (72), such words combinations are adapted in a particular way: borrowed slang sayings that are more often used are adapted both phonetically and morphologically, e.g.: pa polnai (Russ. по по́лной), pa polnai programe (pragrame) (Russ. coll. по по́лной програ́мме), ра polnai katūšse (Russ. vern. по по́лной кату́шке) meaning 'to the maximum'. Only phonetically adapted word combinations are rarely used: $\downarrow p a($ po) polnoi, $\downarrow p a($ po) polnoi programe (pragrame), (po) polnoi katūšske, and the adverb itself in a form * polnoi is not individually used in Lithuanian; it is always only polnai, a standard ${ }^{7}$ derivation of suffix -ai from adj. polnas, - a (turi kelias pozicijos-nuo polnai gulinos iki sedimos. // Krc uzregistravau vakar,sutvarkiau viska polnai // Idealios bukles, polnai veikiantis, visi laidai). It should be emphasized that in slang it is rather common that due to the specificity of use (stability) of stable word combinations, a frequently used saying can be also derived from a phonetically adapted, specific form e.g., programe, polnoi. In slang only the adverb polnai 'fully' is used independently; also in slang a long established standard language borrowing programa keeps the form of a Russian morphologically unadapted prepositional pronoun in locative case programe (Russ. програ́мме), which is not used independently in slang and such a case form does not exist in slang. The above-mentioned sayings also have morphologically adapted,

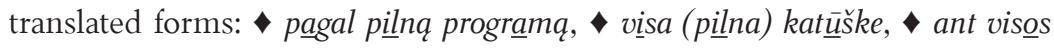
(pilnos) katūuškès 'to the maximum'.

Another illustrative example with a slang word is prikolas (Russ. slang прико́л), which has a morphologically-adapted ending and is inflectional - it is a standard integration into the inflectional or derivational system. If the form of this slang word belongs to a stable word combination, such word

7 Hybrid derivatives of suffix -ai from adverbial adjectives of Russian origin are the most common derivatives in Lithuanian slang. 
combinations are affected in a limited way by regular rules: a form that looks like a case form, functionally can be not a case or a lexical idiomaticity may occur (Čermák 2007: 77-82; Baldwin, Kim 2010: 269). For instance, in the word combination $\downarrow$ ра (ро) prikolum (Russ. slang по прико́лу) 'for fun' the form * prikolum is not used independently, it is always a part of an adverbial saying: ziuriu, kai kuriems nedasuto, kad cia viskas po prikolum eina? // pamirsau paminet, kad mano gimtadienis balandzio 1, tai visi kazkodel man dovanas pa prikolum dovanoja. In a nonstandard language there are more forms of saying adapted in several variants (morphologically as well): $\downarrow p a(p o)$ prikolam (prikolom), dèl prikolo (translated from Russ. slang для прико́ла), prikolo 'for fun; nothing serious.

The majority of adverbialized prepositional constructions or adverbial phraseological word combinations are borrowed from Russian or are loan translations: $\downarrow d a$ (do) lampočki (Russ. coll. до ла́мпочкu) 'whatever, $\downarrow i k i$ lemputès (translated from Russ. coll. до ла́мпочки) 'whatever', pa (ро) barabanu (Russ. vern. по бараба́ну) 'does not matter, whatever', ir vsio takoje (Russ. coll. и всё тако́e) 'and so forth', v žŏpu (Russ. vulg. в жо́ny) 'screw it; to the maximum', po prostu (Pl. po prostu) 'just, simply, dèl ponto (translated from Russ. cf. для по́нта) 'not seriously; for fun', ne prikolas 'seriously, really badly', na ura (Russ. на ypá) 'anyhow', pa (ро) liubomu (Russ. coll. по-любо́му) 'either way, anyway'...

Some established word combinations with a changed meaning have come into general slang from criminal slang: ne zapadlo (Russ. pris. crim. slang не западлó) 'no shame', ant zapadlo 'to try intentionally harm, on purpose', $v$ paddlu (Russ. slang в па́длy) 'shame', per blata, po (рa) blátu (Russ. coll. по бла́my) 'unofficially, illegally'.

In Lithuanian slang there are also euphonic combinational adverbs, derived from ideophones and almost all of them came as borrowings from Russian or through the mediation of Russian. Euphony (i.e. rhyme, rhythm, alliteration) additionally binds word combinations into a semantic unit, and sonority helps the combinations to maintain their consistency, to make them phraseological word combinations: tiap liap (Russ. coll. mяn-ляn) 'uncarefully', šaltai baltai (Russ. vern. шалта́ŭ-болта́ŭ) 'not seriously', ša char máchar (šăcher mácher, ša $\underline{a} k a r$ makkar) (Pl. coll. szacher-macher) 'fraudulently, illegally', fịti mịti (cf. Russ. crim. slang múmu-мúmu 'money') 'fraudulently',

8 Transliterated borrowed adverbial word-combinations are usually stressed in the same way as they are stressed in the language they originate from: po prostu (Pl. po prostu), v padlu (Russ. žarg. в па́длy), v natūre (Russ. vern. в нату́pe), za adno (Russ. за однó), etc. 
raz dva 'one, two and finished' (cf. Russ. раз, два и гото́во), сар сатар (Russ. coll. yán-yapán 'to catch') 'surreptitiously', taram baram (cf. Russ. mápb-6ápы 'chatter') 'and so on', tiutel' ka v tiutel' ku (Russ. coll. тю́телька в тю́тельку) 'very precisely'.

The particle bele (bile) borrowed from Polish (cf. Pl. byle), together with the Lithuanian adverbs for when, where, how, how much, forms a number of hybrid adverbs according to the Polish combinational model (cf. Pl. byle gdzie - Lith. bele kur): bele (bille, belen, billen) kaip (cf. Pl. byle jak 'anyhow') 'haphazardly; wretchedly; , bele (bile, belen, bilen) kada 'whenever',

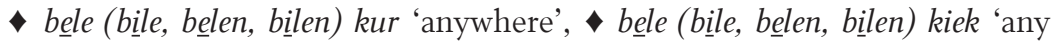
amount', bele (bile) tik (cf. P1.byle tylko) 'just; only, only this way'.

In slang, a popular vulgarism chui forms a number of adverbial word combinations: dachuja ir bǐški (su bišskiu) (cf. Russ. vulg. Әо хуя́ и бо́льше) 'very much', pol chuja (Russ. vulg. пол ху́я), s pol chuja (Russ. vulg. с пол ху́я) 'not bad, quite good', chui s nim (Russ. vulg. хуй с ним) 'let it ride', - chui znajiet (znajet, znajit) (Russ. vulg. хуй знáem) 'nobody knows', ne (ni, nie) za chui (Russ. vulg. не (ни) за хуй) 'no way, not in any circumstances', \a nẹchui (Russ. vulg. за нéxyŭ) 'not in any circumstances, no way', nẹchui delat' (Russ. vulg. не́хуй де́лать) 'easy, pretty easy'. Analogous word combinations are formed with other adverbs as well: nefig (nêchren) delat' 'very easily, simply', za nẹchren 'not in any circumstances, no way.

The negative particle of Russian не, if not stressed, turns into ни, e.g.: где > нигде́, како́й> никако́й, кто > никто́. The negative particle ni (Russ. $н и$ 'neither, not', Pl. $n i$ 'neither, not', nie 'not', Belarus. $н i$ 'neither, not') is used individually in stable word-combinations: ni ni (Russ. coll. ни-ни́ 'no way', ни 'neither, not', Belarus. $н i-\mu i)$ 'no way; by no means; completely nothing; nothing at all', ni to (cf. Russ. coll. ни то ни друго́е 'neither this nor that') 'not this, not in this way', ni to, ni to (cf. Russ. coll. ни то ни друго́ 'neither this nor that'; Pl. ni to, ni owo 'neither this nor that', ni tak, ni siak 'neither one thing nor the other') 'neither this nor that; neither one thing nor the other', kažkas ni to (cf. Russ. что́-то ни то) 'something wrong, something is not right'.

\section{Conclusions}

1. The study reveals that adverbs of Slavic origin, as foreign linguistic units appearing in the context of another language, undergo assimilation - they are transformed in one way or another by adaptation to the linguistic system. 
2. In Lithuanian slang, many adverbs (104; 48.2\%) with the suffix -(i)ai are formed from suffixal adjectives of Slavic origin (mostly Russian). The most productive suffixes of them are -nas $(37 ; 35.6 \%)$ and -ovas $(33 ; 31.7 \%)$. Others are not so common: -(i)avas (12; 11.5\%), -skas (7; $6.7 \%)$, -telnas ( $5 ; 4.8 \%)$, -nutas ( $5 ; 4.8 \%)$, -ovatas (-avotas) $(3 ; 2.9 \%)$, $-y v a s(2 ; 1.9 \%)$. The analysis has indicated a clear systematic feature: of all hybrid derivatives of the suffix -ai, the largest number (67.3\%) are for hybrid adverbs the root words of which are precisely those with the most productive suffixes -nas and -ovas. The remaining adjectivialized suffixes are rarer in the Lithuanian slang, and it is no coincidence that they are not productive in Slavic languages either.

3. In the section "Derivatives with suffix -ai from adjectives without suffixes), derivatives from Russian adjectives without suffixes dominate as well $(17 ; 7.9 \%)$.

4. The number of borrowed adverbs without formants is high $(22 ; 10.2 \%)$. These are mostly phonetically and orthographically adapted Slavic words.

5. The article discusses $72(33.3 \%)$ adverbialized word combinations of Lithuanian slang. Most of the adverbialized prepositional constructions or adverbialized phraseological compounds are phonetically and orthographically adapted borrowings or loan translations from Russian. The slang terms also include highly variable adverbial word combinations, e.g., with Polish particle bele (Pl. byle).

6. Due to the influence of territorial dialects and other languages, slang adverbs are characterised by systematic variation of the root vowel /e/, / ie/ with diphthongised or other qualitatively altered vowels. There is some variation in the pronunciation of the vowels /a/ and /o/ in adverbs, since in unstressed syllables of Russian words a reduced /a/ is pronounced instead of $/ \mathrm{o} /$.

General conclusion. The adaptive features of the studied slang Slavic adverbs are determined by systematic patterns: (a) slang lexis is adapted phonetically and orthographically according to the principle of substitution of foreign phonemes as close as possible to their own, (b) Slavic slang lexis tends to copy derivational models and integrate into the derivational and inflectional paradigms of Lithuanian: morphological features are taken from Slavic languages and specifically transformed in the system of Lithuanian, (c) a part of slang words remains morphologically unadapted only due to the adverb-specific feature - limited inflectionability, (d) variability of borrowed slang words appears due to spontaneous adaptation to the features of the recipient language. 


\section{Abbreviations}

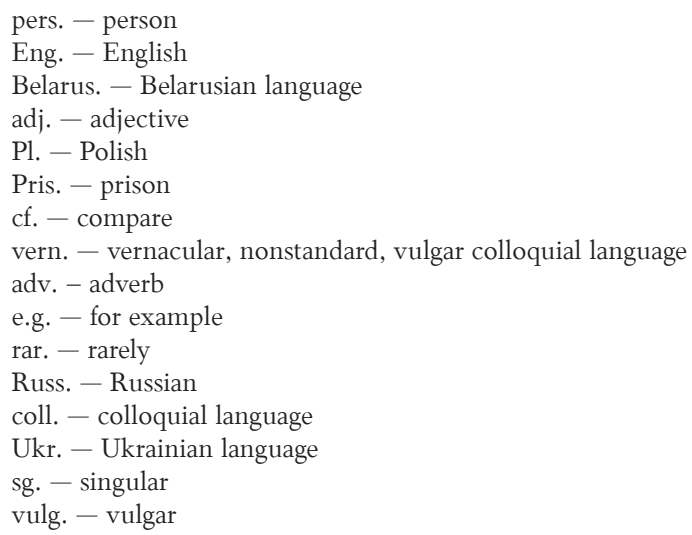

\section{Lexicographic sources}

Czeszewski, Maciej. 2006. Słownik polszczyzny potocznej. Warszawa: Wydawnictwo Naukowe PWN.

Kudirka, Robertas. 2012. Lietuvių kalbos žargono ir nenorminès leksikos žodynas. Kaunas: Technologija,

Kveselevič, Dmitrij. 2005. Tolkovyj slovar' nenormativnoj leksiki russkogo jazyka. Moskva: Astrel'. Mokienko, Valerij, Tat'jana Nikitina. 2000. Bolšoj slovar' russkogo žargona. Sankt-Peterburg: Norint.

Vaitkevičiūtè, Valerija. 2003. Didysis lenkų-lietuvių kalbų el. žodynas. Marijampolè: M. Martišienès vertejų biuras.

\section{Literature}

Anušauskas, Arvydas. 1996. Lietuvių tautos sovietinis naikinimas 1940-1958 metais. Vilnius: Mintis.

Avanesov, Ruben. 1984. R R Rsskoe literaturnoe proiznošenie. Moskva: Prosveščenie.

Baldwin, Timothy, Su Nam Multiword Expressions. Nitin Indurkhya, Fred Damerau (eds).

Kim, 2010.

Handbook of Natural Language Processing. Boca Raton: CRC Press, 267-292.

$\mathrm{BSŽ}=$ Pakerys, Antanas (red.). 2004. Bendriniai XX a. spaudos žodžiai: dažninis žodynas, Vilnius: MELI.

Chambers, Jack, Peter Dialectology. Cambridge: CUP.

Trudgill. 2004.

Čepienè, Nijolè. 2006.

Lietuvių kalbos germanizmai ir ju fonetinès ypatybès. Vilnius: LKI.

Čermák, František. 2007. Foundations and Principles on Phraseology and Idiomatics. Czech and general phraseology. Praha: Karolinum, 73-128.

DLKG $=$ Ambrazas, Vytautas (red.). 2005. Dabartinès lietuviu kalbos gramatika. Vilnius: MEL. 
Durkin, Philip. 2014.

Durrell, Martin. 2004.

Filipović, Rudolf. 1980.

Fischer, Roswitha, Hanna Pułaczewska (eds.). 2008.

Girčiené, Jurgita. 2005.

Girčienè, Jurgita. 2012.

Gorbačevič, Kirill. 1989.

Görlach, Manfred. 2002. GWJP =

Irwin, Mark. 2011.

Jakaitienè, Evalda. 2009.

Kardelis, Vytautas, 2009.

$\mathrm{KP}=$

$\mathrm{KPP}=$

$\mathrm{LKE}=$

$\mathrm{LKG}=$

Pakerys, Jurgis. 2014.

Pakerys, Jurgis. 2016.

Paulauskienè, Aldona. 2004.

Paulauskiene, Aldona. 1994.

$\mathrm{RG}=$

Rimkutè, Erika, Jūrate

Raižytè. 2010.

Sharp, Harriet. 2001.

Sunde, Anne M. 2018.

Tininis, Vytautas. 2008.
Borrowed Words: A History of Loanwords in English. Oxford: OUP.

Sociolect. Ulrich Ammon (ed.). Sociolinguistics. An International Handbook of the Science of Language and Society. Vol. 3. Berlin: Walter de Gruyter, 200-205.

Transmorphemization: Substitution on the morphological level reinterpreted. Studia Romanica et Anglica Zagrabiensia 25 (1-2), $1-8$.

Anglicisms in Europe: Linguistic Diversity in a Global Context. UK: Cambridge Scholars Publishing.

Naujuju skolinių atitikmenys: struktüra ir vartosena. Vilnius: LKI. Naujoji lietuviu kalbos leksika. Vilnius: Edukologija.

Normy sovremennogo russkogo literaturnogo jazyka. Moskva: Prosveščenie.

English in Europe. New York: OUP.

Grzegorczykowa, Renata (red.). 1999. Gramatyka współczesnego języka polskiego: Morfologia. T. 2. Warszawa: Naukowe PWN.

Loanwords in Japanese Amsterdam. Philadelphia: Benjamins Publishing Company.

Leksikologija. Vilnius: VUL.

Šiaurès rytų aukštaičiai vilniškiai: ribos ir diferenciacija. Vilnius: VU leidykla.

Mikulènienė, Danguolè (sud.). 2005. Leksika: skolinių vartojimas. D. 4. Vilnius: Petro ofsetas.

Paulauskienè, Aldona (sud.). 1985. Kalbos praktikos patarimai. Vilnius: Mokslas.

Ambrazas, Vytautas (red.). 1999. Lietuviu kalbos enciklopedija. Vilnius: MELI.

Ulvydas, Kazys (red.). 1971. Lietuviu kalbos gramatika. T. II. Vilnius: Mintis.

Naujųjų skolinių duomenų bazès veiksmažodžių morfologija. Taikomoji kalbotyra 3.

Morphological adaptation of adjectival borrowings in modern Lithuanian. Baltistica, 51 (2), 239-269.

Lietuvių kalbos kultūra. Kaunas: Technologija.

Lietuvių kalbos morfologija. Vilnius: MELI.

Švedova, Natal'ja (ped.). 1980. Russkaja grammatika. Fonetika. Slovoobrazovanie. Morfologija. T. 1. Moskva: Nauka.

Morfologinis skolinių adaptavimas lietuvių kalboje. Lietuviu kalba 4.

English in Spoken Swedish: A Corpus Study of Two Discourse Domains. Stockholm: AWI.

A typology of English borrowings in Norwegian. Nordic Journal of English Studies 17, 71-115.

Sovietų Sajungos politinès struktūros Lietuvoje ir ju nusikalstama veikla: antroji sovietine okupacija(1944-1953). Vilnius: Margi raštai. 
Treffers-Daller, Jeanine. Mixing Two Languages: French-Dutch Contact in a Comparative 1994. Perspective. New York: Gruyter, 1994.

Urbanavičiené, Jolita. 2018. Baltų *ā, *ē diftongizacija vidurinès ir jaunesniosios kartos rytų aukštaičių vilniškių kalboje. Rytu aukštaičiu patarmé: kaita ir pokyčiai. Vilnius: Baltijos kopija, 59-82.

Urbutis, Vincas. 2009. Z Žodžių darybos teorija. Vilnius: MELI.

Vaicekauskienè, Loreta. $\quad$ Naujieji lietuviu kalbos svetimžodžiai: kalbos politika ir vartosena. 2007. Vilnius: LKI.

Valeckienè, Adelè. 1967. Kitų kalbų kilmès žodžiai lietuvių kalbos morfologinèje sistemoje. Vytautas Ambrazas (red.). Lietuvių kalba tarybiniais metais. Vilnius: LKLI, 108-128.

Wohlgemuth, Jan. 2009. A Typology of Verbal Borrowings. New York: De Gruyter Mouton.

Robertas Kudirka

Kalbų, literatūros ir vertimo studijų institutas

Vilniaus Universiteto

Kauno fakultetas

Muitinés g. 8, LT-44280

Kaunas, LIetuva

robertas.kudirka@knf.vu.lt 


\section{Appendix}

\section{Hybrid derivatives with suffix -ai in Lithuanian slang from suffixal Slavic adjectives}

\subsection{Derivatives with suffix -ai from adjectives with the suffix -nas}

davolnai 'with satisfaction' (: davolnas, - $a$; cf. Russ. adv. дово́льно), gliüčnai 'hardly functioning' (: gliúčnas, - $a$; cf. Russ. adv. slang глю́чно), grūznai, gruzznai 'sluggishly' (: grūzznas, gruzznas, $-a$; cf. Russ. adv. гру́зно), interesnai 'interestingly' (: interesnas, - $a$; cf. Russ. adv. интере́сно), kyslótnai 'valiantly' (: kyslótnas, kislotnas, -a, cf. Russ. adv. slang кисло́тно), móčnai 'firmly' (: močnas, -a; cf. Russ. adv. мо́щно), nachaliavnai 'for free' (: nachaliavnas, $-a$; cf. Russ. adv. vern. нахаля́вно), našarnai 'for free' (: našarnas, -a), navarotnai 'extravagantly' (: navarotnas, $-a$; cf. Russ. adv. slang наворо́тно), nejasnai 'not clearly' (: nеjassnas, -a; cf. Russ. adv. нея́сно),

nevjebenai 'beyond description' (: nevjebennas, $-a$; cf. Russ. adv. vulg. невъебе́нно),

nevtemnai 'off the point' (: nevtemnas, -a, cf. Russ. adv. coll. невте́мно), pachabnai 'poorly' (: pachabnas, -a; cf. Rus. adv. vern. nохáбно), padpolnai 'underground, illegally' (: padpolnas, $-a)$, paliótnai 'full of drive (: paliontnas, $-a)$, pamoinai 'contemptibly' (: pamoinas, -a; cf. Russ. adv. помо́йно), parašñai 'poorly' (: parašnas, - $a$; cf. Russ. adv. slang пара́шно), plótnai 'tightly' (: plotnas, $-a$; cf. Russ. adv. пло́тно), podpolnai rarely 'underground, illegally' (: podpolnas, -a; cf. Russ. adv. подпо́льно), pravalnai 'unsuccessfully' (: pravalnas, - $a$; cf. Russ. adv. прова́льно), prikolnai 'impressively' (: prikolnas, -a; cf. Russ. adv. slang прико́льно), striomnai 'uncarefully' (: striomnas, $-a$; cf. Russ. adv. slang стрёмно), tapornai 'roughly' (: tapornas, -a; cf. Russ. adv. топо́рно), tarmozznai 'slowly' (: tarmoznas, -a; cf. Russ. adv. тормо́зно), vięčnai, večnai 'forever' (: viečnas, vẹčnas, $-a$; $\mathrm{cf}$. Pl. adv. wiecznie, Russ. adv. ве́чно), zavodnai 'receptively' (: zavoِdnas, -a; cf. Russ. adv. coll. заво́дно). 


\subsection{Derivatives with suffix -ai from adjectives with the suffix -ovas}

fuflovai 'fraudulently' (: fuflovas, - $a$; cf. Russ. adv. slang фуфло́во), grūzovai 'slugishly' (: grūzovvas, $-a)$,

kaifóvai 'enjoyably' (: kaifọvas, -a; cf. Russ. adv. slang кайфóвo), lažovai 'poorly' (: lažôvas, -a; cf. Russ. adv. slang лажо́во), liuksovai 'perfectly' (: liuksovas, -a; cf. Russ. adv. coll. лю́ксово), liuksusovai 'perfectly' (: liuksusovas, -a; cf. Pl. adv. luksusówo), nechujovai 'not bad' (: nechujovas, -a; cf. Russ. adv. vulg. нехуёво), neputiovai 'looking bad' (: neputiovas, - $a$; cf. Russ. adv. coll. непутёво), nuliovai 'completely anew' (: nuliovas, - $a$; cf. Russ. adv. coll. нулёво), putiovai 'greatly' (: putiovas, -a; cf. Russ. adv. coll. nymёвo), stopudovai 'guaranteed' (: stopudovas, -a; cf. Russ. adv. coll. cmonyдóвo), šyzovai, šizovai 'crazily' (: šyzovas, -a; cf. Russ. coll. шизо́во), talkôvai 'understandably' (: talkôvas, -a; cf. Russ. толко́во).

\section{Derivatives with suffix -ai from Slavic adjectives without suffixes}

polnai 'completely' (: polnas, - $a$; cf. Russ. adv. по́лно), pošlai 'in a vulgar manner' (: pošlas, - $a$; cf. Russ. adv. nóuло), šūstrai 'extraordinarily; fashionably; impressively' (: šûustras, - $a$; cf. Russ. adv. coll. uýcmpo), tọčnai 'accurately' (: tọčnas, - $a$; cf. Russ. adv. то́чно), tūpai 'stupidly' (: tūpas, - $a$; cf. Russ. adv. mýno), žestôkai 'cruelly' (: žestôkas, - $a$; cf. Russ. adv. жесто́ко), žóstkai 'strongly' (: žostkas, -a; cf. Russ. adv. coll. жёстко).

\section{Slang adverbs without formants}

chier, cher (Russ. vulg. xep) 'any; nothing', čiki (cf. Russ. slang чúкu) 'well; perfectly', lafa (Russ. vern. лафá) 'well, greatly', mímo (Pl mimo, Russ. ми́мо) 'by', šabąš (cf. Russ. vern. maбáu) 'bad, poorly', ticharia (Russ. vern. втихаря́, в тихаря́) 'secretly', zaprasta (Russ. coll. зánpocmo) 'easily, simply'. 


\section{Adverbialized word combinations of Slavic origin}

- ant bajerio (Pl. coll. na bajer) 'for laughs',

- ant pilno (viso) gazzo (cf. Russ. vern. на по́лном газу́) 'at maximum',

- be tolko (Russ. без то́лку) 'pointlessly; disorderly',

- čiki brikki (Russ. coll. чúкu-бри́кu),

- čiki čiki (cf. Russ. coll. чи́ки-чи́ки) 'greatly; precisely',

- čiki pikki, čikis pikis (Russ. cf. чи́кu-пúкu),

- čiki puki (Russ. cf. чи́кu-пýкu),

- dal šse nékuda (niekuda) (Russ. coll. Әа́льше не́кудa) 'there is nowhere else',

- dalše nekuda (Russ. vern. да́льше не́куда) 'nothing else’,

- na vsie (vse) sto (Russ. vern. на все сто) 'surely, one hundred per cent',

- pa natūre (Russ. no нamýpe) 'indeed, inherently',

pats gazas 'exactly; greatly, the best',

- prosto tak (Russ. coll. прócmo так) 'simply, not so good',

- savo chodu (translated from Russ. свои́м хо́дом) 'independently, on smb's own',

- tol'ka (tol'ko) tak (Russ. то́лько так) 'as it has to be',

- toll'ko (tol' ka) pessnia (piesnia) 'fluently',

- v natūre (Russ. vern. в натýpe) 'for real',

- za adno (odno) (Russ. за однó) 'at the same time'.

KOPSAVILKUMS

\section{Slāvu cilmes lietuviešu slenga apstākḷa vārdi}

\section{Robertas KUDIRKA}

Rakstā morfolog̣iski analizēti slāvu cilmes (pārsvarā krievu, dažkārt poḷu un baltkrievu) lietuviešu slenga apstākḷa vārdi (215), kas atlasīti no lietuviešu slenga vārdnīcas Lietuvių kalbos žargono ir nenorminès leksikos žodynas (2012). Analīzei ir izvēlēti četri apstākḷ̆a vārdu veidi: hibrīdatvasinājumi ar piedēkli -ai no īpašỉbas vārdiem ar piedēkli un bez tā, apstākḷa vārdi bez formantiem un adverbēti vārdu savienojumi. Analīzes mērḳis ir identificēt sistemātiskus morfolog̊iskos modeḷus un adaptācijas pazīmes. Analīze parādỉja, ka lietuviešu slengā slāvu apstākḷa vārdi tiek fonētiski un ortogrāfiski pielāgoti pēc iespējas tuvāk pašcilmes vārdiem pēc citvalodu fonēmu aizstāšanas principa. Slāvu cilmes slenga leksikā ir tendence kopēt atvasinājumu modeḷus un integrêt tos lietuviešu valodas locīšanas paradigmās: morfoloǵiskās pazīmes ir pārņemtas no slāvu valodām un īpaši pārveidotas lietuviešu valodas sistēmā; aizgūtā slenga mainīgums parādās, spontāni pielāgojoties mērḳvalodas iezīmēm. 